\title{
A novel thermostable alkaline histamine oxidase from Glutamicibacter sp. N1A3101, induced by histamine and its analogue betahistine
}

\author{
Hossein Sadeghi ${ }^{1}$, Sareh Arjmand ${ }^{2}$, Seyed Omid Ranaei Siadat ${ }^{2 *}$, Jamshid Fooladi ${ }^{3}$ \\ and Gholamhossein Ebrahimipour ${ }^{1 *}$
}

\begin{abstract}
Biogenic amines (BAs) are low molecular weight organic bases formed by natural amino acids decarboxylation and trigger an array of toxicological effects in humans and animals. Bacterial amine oxidases enzymes are determined as practical tools to implement the rapid quantification of BAs in foods. Our study set out to obtain a new efficient, amine oxidase enzyme for developing new enzyme-based quantification of histamine. The soils from different sources were screened using histamine as sole carbon and nitrogen sources, and histamine oxidase producing bacteria were selected and identified using specific primers for histamine oxidase (HOD) gene. The HOD gene of six strains, out of 26 isolated histamine-utilizing bacteria, were amplified using our designed primers. The HOD enzyme from Glutamicibacter sp. N1A3101, isolated from nettle soil, was found to be thermostable and showed the highest substrate specificity toward the histamine and with no detected activity in the presence of putrescine, cadaverine, spermine, and spermidine. Its oxidation activity toward tyramine was lower than other HOD reported so far. The isolated enzyme was stable at $60^{\circ} \mathrm{C}$ for 30 min and showed pH stability ranging from 6 to 9. Furthermore, we indicated the induction of identified HOD activity in the presence of betahistine as well, with nearly equal efficiency and without the consumption of the substrate.
\end{abstract}

Keywords: Histamine oxidase, Histamine, Betahistine, Glutamicibacter sp. N1A3101

\section{Introduction}

BAs are non-volatile, low molecular weight nitrogenous organic bases which are formed through decarboxylation of amino acids by amino acid-specific decarboxylases. These amines are naturally produced and degraded in humans, animals, plants, and microorganisms and result in numerous biological functions (Lee and Kim 2013; Alvarez and Moreno-arribas 2014; Velut et al. 2019). Amino acid decarboxylases are usually found in spoilage and other food microorganisms

\footnotetext{
*Correspondence: o_ranaei@sbu.ac.ir; g-ebrahimi@sbu.ac.ir

1 Department of Microbiology \& Microbial Biotechnology, Faculty of Life

Sciences and Biotechnology, Shahid Beheshti University, Tehran, Iran

2 Protein Research Center, Shahid Beheshti University, Tehran, Iran

Full list of author information is available at the end of the article
}

(Alvarez and Moreno-arribas 2014). Therefore, the BAs compounds are present to varying degrees in many of fermented and non-fermented foods, such as fishes, meats, cheeses, sausages, and wines. The major BAs related to spoilage in meat and fish are putrescine (1,4-diaminobutane), cadaverine (1,5-diaminopentane), tyramine (2-(p-hydroxyphenyl) ethylamine), and histamine (2-(4imidazolyl) ethylamine. The consumption of foods containing a high concentration of BAs may cause food intoxication and eventually leads to the organoleptic decay of the food products (Alvarez and Morenoarribas 2014). Therefore, these compounds potentially are considered substantial indicators of food quality.

Among BAs, histamine is the most biochemically active amines and has been widely addressed as one of the fundamental primary amines in food analysis, 
especially in fishery industries (Ito et al. 2009). Scombroid and non-scombroid fish have been shown to have a high concentration of free L-histidine (histamine precursor) in their skeletal muscles (Biji et al. 2016). Inappropriate manipulation, freezing or conservation of fish can result in histidine decarboxylase enzyme activity and decarboxylation of histidine to histamine. Due to the adverse effects of histamine in human health, measuring its concentration is highly essential in evaluating food quality. Histamine assay could be an effective safety program in seafood processors to control histamine health hazards (Köse et al. 2011). Measurement of histamine in fish is traditionally performed by chromatographic methods, which is a time consuming, complicated, and expensive technique. Therefore developing rapid and cost-effective methods such as immuno-enzymatic assay, immuno-polymerase chain reaction method, chromogenic sensing, amperometric biosensing, and enzymatic assay have received major attention in recent years (Yang et al. 2019).

Among them, enzymatic determination of histamine using HOD enzymes is considered as an easy, effective strategy. The enzyme oxidatively deaminates the primary amine to imidazole acetaldehyde, hydrogen peroxide $\left(\mathrm{H}_{2} \mathrm{O}_{2}\right)$, and ammonia $\left(\mathrm{NH}_{3}\right)$. The generated $\mathrm{H}_{2} \mathrm{O}_{2}$ can simply be measured by spectrophotometry or fluorometry methods (Sekiguchi et al. 2001). Several copper-containing amine oxidases with high affinity to histamine have been found in Aspergillus nigerAKU3302 (Suzuki et al. 1971), Arthrobacter globiformis (Shimizu et al. 1994), Arthrobacter crystallopoietes KAIT-B-007 (Sekiguchi et al. 2004), Pisum sativum (McGowan and Muir 1971) and mammalian sources (Pionetti 1974; Isobe et al. 1980). Some of them have been developed for the rapid detection of histamine in food processes. Although these enzymes exhibited a high affinity to many BAs such as tyramine, the enzyme with significant specificity to histamine is highly demanded.

We conducted this study under the assumption that in soil histamine co-exists with histamine-producing plants such as spinach and nettle. The soil near these plants can be considered as histamine oxidizing microorganism's resources. Therefore, we have focused on the nettle grows soils to find a histamine oxidase with high specificity toward histamine. HOD need histamine induction to be expressed. Histamine is an expensive substrate for commercial production; therefore, we were looking for a cheaper alternative for enzyme production. Betahistine, a histamine analogue, showed promising results for the induction of HOD in its natural producing microorganism.

\section{Materials and methods Chemicals}

Histamine dihydrochloride, putrescine dihydrochloride, cadaverine dihydrochloride, peroxidase, and N-Ethyl$\mathrm{N}$-(2-hydroxy-3-sulfopropyl)-3,5-dimethoxyaniline (DAOS) were obtained from Wako Pure Chemical (Japan). Spermidine trihydrochloride, and spermine tetrahydrochloride were purchased from Sigma Chemicals (USA). 4-aminoantipyrine was purchased from Biobasic Chemical Industries (Canada). Betahistine supplied from Shahredaru pharmaceutical co. (Iran). All reagents were analytical grade.

\section{Isolation of histamine metabolizing bacteria}

To isolate the histamine-degrading bacteria, different soil samples around the roots of stinging nettle (Urtica dioica) were collected from different regions of Iran. A spoonful (approximately $5 \mathrm{~g}$ ) of each soil sample was suspended in $100 \mathrm{ml}$ of a screening medium consisting of $0.1 \%(\mathrm{w} / \mathrm{v})$ histamine dihydrochloride, $0.05 \%$ $(\mathrm{w} / \mathrm{v}) \mathrm{K}_{2} \mathrm{HPO}_{4}, 0.02 \%(\mathrm{w} / \mathrm{v}) \mathrm{MgSO}_{4} \cdot 7 \mathrm{H}_{2} \mathrm{O}, 0.001 \%(\mathrm{w} / \mathrm{v})$ $\mathrm{FeSO}_{4} \cdot 7 \mathrm{H}_{2} \mathrm{O}$ in tap water at $\mathrm{pH}$ 7.0. After incubation at $30{ }^{\circ} \mathrm{C}$ for 7 days, one $\mathrm{mL}$ of culture was inoculated in $100 \mathrm{~mL}$ of the same fresh medium and incubated for the next 2 days in the same condition. This step was repeated two times. After enrichment, $0.1 \mathrm{ml}$ of the culture medium was plated out onto agar-solidified screening medium and incubated at $30{ }^{\circ} \mathrm{C}$. The colonies appeared on the plates after $24-48 \mathrm{~h}$, were transferred to $20 \mathrm{ml}$ of Luria-Bertani (LB) medium (tryptone $10 \mathrm{~g} / \mathrm{L}$, yeast extract $5 \mathrm{~g} / \mathrm{L}, \mathrm{NaCl} 10 \mathrm{~g} / \mathrm{L}$ ), and cultivated at $30^{\circ} \mathrm{C}, 115 \mathrm{rpm}$ for $12 \mathrm{~h}$.

\section{Amplification of putative HOD gene and extraction of HOD enzyme}

The DNA sequence of HOD from the different bacterial genus (Additional file 1: Table S1) was obtained from NCBI GenBank and aligned by ClustalW online software (http://www.ebi.ac.uk/Tools/msa/clustalo). The identified conserved sequences were used to design the PCR primers for the amplification of newly isolated HOD genes. PCR amplifications were performed by applying the initial denaturation at $95{ }^{\circ} \mathrm{C}$ for $5 \mathrm{~min}$, followed by 30 cycles of amplification $\left(94{ }^{\circ} \mathrm{C}\right.$ for $40 \mathrm{~s}, 52{ }^{\circ} \mathrm{C}$ for $40 \mathrm{~s}$, and $72{ }^{\circ} \mathrm{C}$ for $60 \mathrm{~s}$ ), and with $7 \mathrm{~min}$ of final extension at $72{ }^{\circ} \mathrm{C}$. Genomic DNA of isolated histamine utilizing bacteria was used as template DNA and amplified using the designed primers, (forward: 5'- AACTACGAY TACGGSTTCTACTGG-3' and reverse: 5'- GCATGA TSGGCCAGTCCTC-3). After electrophoresis of PCR results, the bands representing the putative HOD gene 
were purified from agarose gel using QIAquick purification kit (Qiagen, Italy) and sent for sequencing at Bioneer Co. (Korea).

The resulting sequences were blast-analyzed to detect the sequence similarities. Besides, the PCR positive strains were cultivated in $10 \mathrm{ml}$ of the screening medium for $12 \mathrm{~h}$. The grown cells were harvested by centrifugation at $4,000 \mathrm{~g}$ for $10 \mathrm{~min}$ at $4{ }^{\circ} \mathrm{C}$ and washed twice with $0.1 \mathrm{M}$ phosphate buffer $\mathrm{pH}$ 7.0. The resulting cells were resuspended in the wash buffer and sonicated for a total of $5 \mathrm{~min}$ ( $2 \mathrm{~s}$ sonications followed by a $10 \mathrm{~s}$ intervals) at a power setting of $20 \mathrm{kHz}$ under ice-cooling and using a bench-top sonicator. The cells and debris were removed by centrifugation at $12,000 \mathrm{~g}$ for $10 \mathrm{~min}$ at $4{ }^{\circ} \mathrm{C}$, and supernatants were collected and referred to as the crude enzyme extract.

\section{Determination of HOD activity}

The HOD assay was performed according to Sekiguchi et al. (2004) with minor modifications. The assay mixture $(170 \mu \mathrm{L})$ consisting of $1.2 \mathrm{mM}$ histamine dihydrochloride, $1.47 \mathrm{mM}$ DAOS, $2.2 \mathrm{mM} 4-\mathrm{AA}$ and one unit $/ \mathrm{mL}$ horseradish peroxidase in $20 \mathrm{mM}$ potassium phosphate buffer ( $\mathrm{pH}$ 7.0) was preincubated at $37^{\circ} \mathrm{C}$ for $5 \mathrm{~min}$. The obtained cell lysate was diluted with $20 \mathrm{mM}$ phosphate buffer ( $\mathrm{pH} 7.0$ ), and $30 \mu \mathrm{L}$ of the sample was mixed in the assay mixture. The mixtures were incubated for $5 \mathrm{~min}$ at $37{ }^{\circ} \mathrm{C}$, and the $\mathrm{OD}_{600}$ was measured using an Infinite M200 microtiter plate reader (Switzerland). The mixture without substrate was considered as negative control. One unit of activity was defined as the amount of enzyme which liberated $1 \mu \mathrm{mol}$ of hydrogen peroxide per min under the specified conditions. The amount of $\mathrm{H}_{2} \mathrm{O}_{2}$ was calculated using the standard curve.

\section{Taxonomic identification of HOD producing bacterium}

The isolated strain with the highest HOD activity was identified by $16 \mathrm{~S}$ rRNA sequencing. The genomic DNA was amplified by PCR using the following primers of $16 \mathrm{~S}$ rRNA; 27 F (5'-AGAGTTTGATCMTGGCTCAG-3'), and $1492 \mathrm{R}\left(5^{\prime}\right.$-GGYTACCTTGTTACGACTT- $\left.3^{\prime}\right)$. The PCR program comprised initial denaturation at $95^{\circ} \mathrm{C}$ for $5 \mathrm{~min}$, followed by 30 cycles of amplification $\left(94^{\circ} \mathrm{C}\right.$ for $40 \mathrm{~s}, 52{ }^{\circ} \mathrm{C}$ for $40 \mathrm{~s}, 72{ }^{\circ} \mathrm{C}$ for $60 \mathrm{~s}$ ), and $7 \mathrm{~min}$ of final extension at $72{ }^{\circ} \mathrm{C}$. PCR product was purified by the QIAquick purification kit (Quiagen, Italy) and sequenced by Bioneer Co. (Korea). The obtained sequence was compared with reference 16S rRNA gene sequences available in EzBioCloud database (https://www.ezbiocloud.net/). All the representative sequences were aligned using the Clustalx software package, and the phylogenetic tree was constructed using neighbor-joining method available in
MEGA version 10 software. Bootstrap analysis based on 1000 replications was conducted for evaluating the confidence level of the branch nodes.

\section{Growth profile of selected bacterium and HOD production} The isolated bacterium was cultivated in LB medium at $30{ }^{\circ} \mathrm{C}$ and $115 \mathrm{rpm}$ for $12 \mathrm{~h}$. The grown cells were harvested by centrifugation at $10,000 \mathrm{~g}$ for two $\mathrm{min}$, washed twice with saline and diluted to match the 0.5 McFarland turbidity standard $\left(\mathrm{OD}_{600}=0.13\right.$, approximately $\left.10^{8} \mathrm{CFU} / \mathrm{ml}\right)$. Ten $\mathrm{ml}$ of the prepared dilution was used for inoculation of one $\mathrm{L}$ of basal salt medium (BSM) $\quad\left(0.05 \% \quad \mathrm{~K}_{2} \mathrm{HPO}_{4}, \quad 0.02 \% \quad \mathrm{MgSO}_{4} \cdot 6 \mathrm{H}_{2} \mathrm{O}, \quad 0.001 \%\right.$ $\mathrm{FeSO}_{4} .7 \mathrm{H}_{2} \mathrm{O}, 0.001 \% \mathrm{CaCl}_{2}$, and $0.1 \%$ (v/v) trace elements (70 mg ZnCl$, 100 \mathrm{mg} \mathrm{MnCl}{ }_{2} \cdot 4 \mathrm{H}_{2} \mathrm{O}, 200 \mathrm{mg} \mathrm{CoCl}{ }_{2} \cdot 6 \mathrm{H}_{2} \mathrm{O}$, $100 \mathrm{mg} \mathrm{NiCl} 2 \cdot 6 \mathrm{H}_{2} \mathrm{O}, 20 \mathrm{mg} \mathrm{CuCl}_{2} \cdot 2 \mathrm{H} 2 \mathrm{O}, 50 \mathrm{mg}, 50 \mathrm{mg}$ $\mathrm{NaMoO}_{4} \cdot 2 \mathrm{H}_{2} \mathrm{O}, 26 \mathrm{mg} \mathrm{Na} \mathrm{SeO}_{3} \cdot 5 \mathrm{H}_{2} \mathrm{O}$ and one $\mathrm{ml}$ of $25 \% \mathrm{HCl}$ in $1000 \mathrm{ml}$ distilled water, $\mathrm{pH}$ 8.0)) containing $0.1 \%$ histamine dihydrochloride and $1 \%$ sodium acetate, and incubated for $18 \mathrm{~h}$ at $30{ }^{\circ} \mathrm{C}$, and $115 \mathrm{rpm}$. Ten $\mathrm{mL}$ of cultures were aliquot at regular intervals for monitoring the cell growth by measuring the optical density at $600 \mathrm{~nm}$. Cell lysates were used for the measurement of HOD activity.

\section{Substrate specificity analysis}

Substrate specificity of the crude enzyme was checked by using different BAs, including histamine, tyramine, putrescine, cadaverine, spermine, and spermidine, with the final concentration of $1.2 \mathrm{mM}$. Enzymatic activity on each substrate was determined based on the method described earlier.

\section{Effect of temperature and $\mathrm{pH}$ on enzyme activity}

The effect of temperature on isolated HOD was examined by incubating $30 \mu \mathrm{L}$ of the diluted enzyme with 170 $\mu \mathrm{L}$ substrate solution $(1.2 \mathrm{mM}$ histamine dihydrochloride in $20 \mathrm{mM}$ potassium phosphate buffer $\mathrm{pH}$ 7.0). After incubation for $10 \mathrm{~min}$ at the temperatures from 40 to $70{ }^{\circ} \mathrm{C}$, the reaction mixture was boiled for $5 \mathrm{~min}$ to terminate the reaction. Then, $30 \mu \mathrm{L}$ of mixtures were mixed with $170 \mu \mathrm{L}$ chromogen solution, consisting of $1.47 \mathrm{mM}$ DAOS, $2.2 \mathrm{mM}$ 4-AA, and one unit $/ \mathrm{mL}$ horseradish peroxidase in $20 \mathrm{mM}$ potassium phosphate buffer $(\mathrm{pH} 7.0)$ and incubated for $5 \mathrm{~min}$ at $37^{\circ} \mathrm{C}$. Thermostability was investigated by incubating of the diluted enzyme at the temperatures from 40 to $70{ }^{\circ} \mathrm{C}$ for 10,20 , and $30 \mathrm{~min}$.

The heat-treated enzyme solutions were immediately cooled in ice-bath, and the residual activity was assayed at $37^{\circ} \mathrm{C}$. The relative activity of the enzyme was calculated in comparison with non- heated samples at room temperature. The experiments were performed in triplicate. 
The effect of $\mathrm{pH}$ on the HOD activity was studied using Britton Robinson buffer (buffering range 5.0 to 9.0) with a concentration of $40 \mathrm{mM}$. For $\mathrm{pH}$ stability analysis, the enzyme solution was diluted with Britton-Robinson buffer (buffering range 4.0-11.0). After incubation at $37^{\circ} \mathrm{C}$ for $30 \mathrm{~min}$, the enzyme solution was assayed in the standard reaction mixture for residual HOD activity.

\section{Study the effect of betahistine on the induction of HOD production}

Histamine is relatively expensive, and for running the experiments and induction of HOD gene a cheaper but efficient source was highly desired. Therefore, we chose betahistine, a structural histamine analogue which is relatively cheaper and more affordable, to be assessed as the inducer. For this purpose, three experiments were designed and conducted as follow;

\section{Experiment 1: Betahistine as sole carbon and nitrogen source} $1 \%(\mathrm{v} / \mathrm{v})$ of seed culture $\left(\mathrm{OD}_{600}=0.13\right)$ inoculated to $20 \mathrm{ml}$ of BSM containing $0.1 \%$ Betahistine as sole carbon and nitrogen source. The media were incubated for $24 \mathrm{~h}$, at $30^{\circ} \mathrm{C}$ and $115 \mathrm{rpm}$. Grown cells were harvested from the culture by centrifugation at $4,000 \mathrm{~g}$ for $10 \mathrm{~min}$ at $4{ }^{\circ} \mathrm{C}$, washed twice with a large volume of $0.1 \mathrm{M}$ phosphate buffer ( $\mathrm{pH}$ 7.0), and resuspended in the same buffer for performing HOD assay.

\section{Experiment 2: Betahistine as the sole nitrogen source} $1 \%(\mathrm{v} / \mathrm{v})$ of seed culture $\left(\mathrm{OD}_{600 \mathrm{~nm}}=0.13\right)$ inoculated to $20 \mathrm{~mL}$ of BSM containing $1 \%$ acetate as sole carbon and $0.1 \%$ betahistine as sole nitrogen source. The cells were grown and prepared for HOD assay analysis, as explained above.

\section{Experiment 3: Betahistine as inducer agent}

$1 \%(\mathrm{v} / \mathrm{v})$ of seed culture $\left(\mathrm{OD}_{600 \mathrm{~nm}}=0.13\right)$ inoculated to $20 \mathrm{~mL}$ of BSM containing $1 \%$ acetate as sole carbon and ammonium chloride as the nitrogen source in the presence of $0.1 \%$ Betahistine, and the cells were prepared for HOD assay as explained.

For negative control, the BSM medium containing 1\% acetate as carbon and $0.1 \%$ ammonium chloride as the nitrogen sources, was used. The BSM medium containing $1 \%$ acetate as carbon and $0.1 \%$ histamine dihydrochloride as the nitrogen source was used for positive control.

\section{Results}

PCR amplification of putative HOD gene, and molecular phylogeny of isolated microorganism

The PCR results of the conserved area in six strains from the 26 isolated histamine-utilizing bacteria indicated a sharp band ( 750-1000 bp) that were considered as a putative HOD gene and sent for sequencing (Fig. 1). The strain with the highest measured HOD activity was selected for the $16 \mathrm{~S}$ rRNA gene analysis and identified as the Glutamicibacter sp. N1A3101. The phylogenetic position of the identified strain based on $16 \mathrm{~S}$ rRNA gene sequence analysis has been depicted in Fig. 2. The physicochemical properties of Glutamicibacter sp. N1A3101 have been compared with its phylogenetically closet relative (Glutamicibacter endophyticus) in Table 1.

The detected sequenced HOD gene of the strain N1A3101 showed the highest similarity with HOD form the Arthrobacter globiformis IFO12137 (99\%), and Arthrobacter crystallopoietes KAIT B 007 (80\%) strains, respectively.

\section{Time courses of cell growth and HOD production}

Time course of Glutamicibacter sp. N1A3101growth in BSM medium containing $1 \%$ acetate as carbon and $0.1 \%$ histamine dihydrochloride as nitrogen source has been shown in Fig. 3. After a six h of lag phase, bacterium started to grow exponentially, and at the same

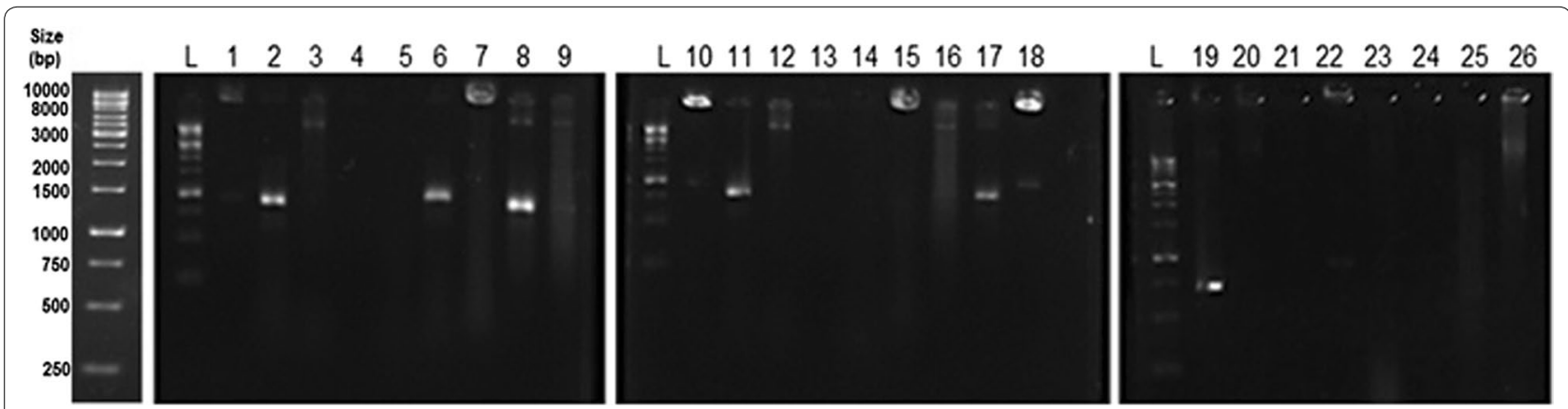

Fig. 1 PCR amplification of genomic DNA from isolated histamine utilizing strains, using HOD primers. The amplified primers in lanes 2, 6, 8, 11, 17, and 19 were considered as putative sequences related to HOD. L, one-kb DNA marker 


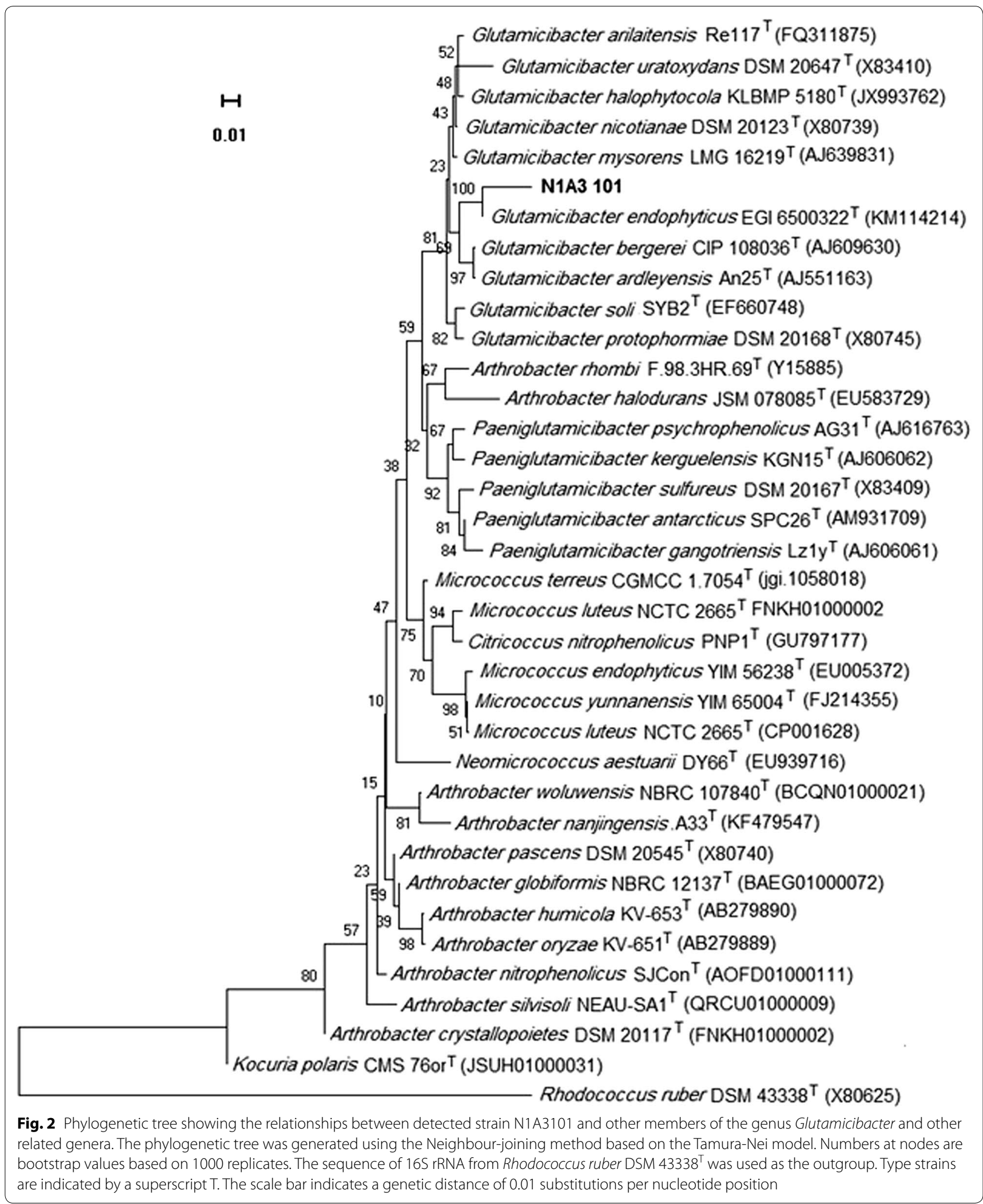


Table 1 Comparison of physicochemical characteristics of strain N1 A3101 and its closest phylogenetic strain

\begin{tabular}{|c|c|c|}
\hline Characteristic & $\begin{array}{l}\text { Glutamicibacter. } \\
\text { sp N1A3101 }\end{array}$ & $\begin{array}{l}\text { G. endophyticu } \\
\text { s(Busse } \\
\text { and Schumann 2019) }\end{array}$ \\
\hline Gram staining & Positive & Positive \\
\hline Catalase & + & + \\
\hline Oxidase & - & - \\
\hline Spore forming & - & - \\
\hline Anaerobic growth & - & - \\
\hline Motility & - & - \\
\hline $\begin{array}{l}\text { Temperature range for } \\
\text { growth }\left({ }^{\circ} \mathrm{C}\right)\end{array}$ & $5-40$ & $5-35$ \\
\hline $\mathrm{NaCl}$ range for growth (\%) & $0-10$ & $0-13$ \\
\hline \multicolumn{3}{|l|}{ Hydrolysis of: } \\
\hline Starch & + & + \\
\hline Casein & + & + \\
\hline Urease & + & + \\
\hline Gelatin & + & + \\
\hline Nitrate reduction to nitrite & - & - \\
\hline \multicolumn{3}{|l|}{ Utilization of: } \\
\hline L-Arabinose & + & + \\
\hline L-Lactose & - & - \\
\hline Glycerol & + & + \\
\hline D-Glucose & + & + \\
\hline D-Fructose & + & + \\
\hline Inulin & + & ND \\
\hline Ascorbate & - & ND \\
\hline Citrate utilization & + & + \\
\hline
\end{tabular}

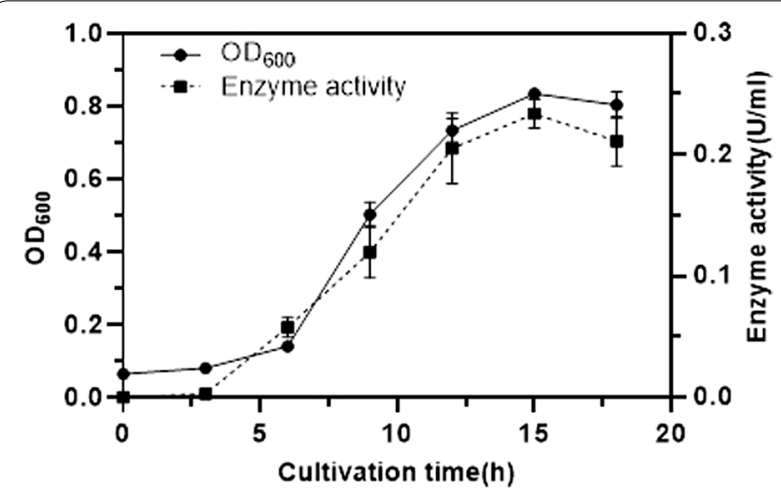

Fig. 3 Time course of Glutamicibacter sp. N1A3101cell growth and HOD activity in BSM medium containing acetate and histamine dihydrochloride as the carbon and nitrogen sources, respectively. The error bars represent standard error $(n=3)$

time, enzyme production increased parallel to the log phase. Maximum growth and enzyme production were observed after $12-15 \mathrm{~h}$ incubation.
Glutamicibacter sp. N1A3101 HOD exhibited substrate specificity for histamine

The crude enzyme showed a high oxidase activity toward histamine $(0.2 \mathrm{U} / \mathrm{mL})$, and a low degree of activity $(\sim 20 \%$ of histamine) against tyramine. No enzyme activity was measured for other tested substrates, including putrescine, cadaverine, spermine, spermidine, and L-histidine (Fig. 4).

The effect of temperature and pH on HOD enzyme activity and stability

The maximum HOD activity was obtained at $40{ }^{\circ} \mathrm{C}$ (Fig. 5a). The thermal stability of the enzyme was shown in Fig. 5b. More than $90 \%$ of HOD activity remained after $30 \mathrm{~min}$ of heat treatment at $40-60{ }^{\circ} \mathrm{C}$. However, a sharp decline was observed after $10 \mathrm{~min}$ of incubation at $70^{\circ} \mathrm{C}$.

As shown in Fig. 5c, d, the optimum pH for the HOD activity was found to be 8.0, and the enzyme showed high stability over the $\mathrm{pH}$ range of $7-9$ at $40{ }^{\circ} \mathrm{C}$ for $10 \mathrm{~min}$ incubation.

\section{Betahistine induces HOD production}

The results related to the effect of betahistine, as the carbon, nitrogen, or both sources, on the induction of HOD expression in Glutamicibacter sp. N1A3101 is summarized in Table 2. According to the obtained results, the bacterium did not consume betahistine as carbon or nitrogen source; therefore, no growth or HOD production was observed. However, in the medium containing acetate and $\mathrm{NH}_{4} \mathrm{Cl}$ as carbon and nitrogen sources (experiment 3); the addition of betahistine led to significant HOD enzyme production $(0.1 \mathrm{U} / \mathrm{ml})$, which was $50 \%$ of enzyme activity measured in positive control. No HOD activity was observed in the negative control.

\section{Discussion}

Histamine is a biologically active amine compound, produced in the different food products due to histidine decarboxylation, and may lead to allergies and food poisoning (Alvarez and Moreno-arribas 2014; Biji et al. 2016). Histamine quantification by enzymatic methods have been emerged as simple, fast and applicable strategies in food industries (Rosini et al. 2014). In the present study, a novel thermostable HOD enzyme whit high specificity toward histamine has been introduced and partially characterized.

We isolated several histamines metabolizing bacteria from nettle soils, using the enrichment culture method. For detection of HOD producing bacteria from other isolates, the PCR primers were designed based on the conserved sequences in other HOD genes.

Among the isolated HOD producing bacteria, the one with the highest Histamine oxidase activity was identified 


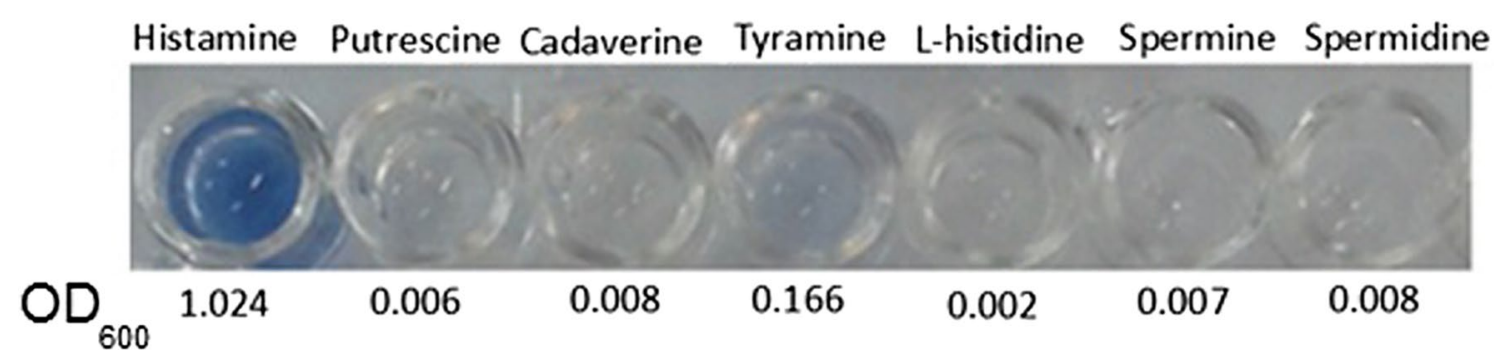

Fig. 4 Substrate specificity of Glutamicibacter sp. N1A3101 HOD against several BAs (absorbance at $600 \mathrm{~nm}$ ) indicated its high specificity for histamine
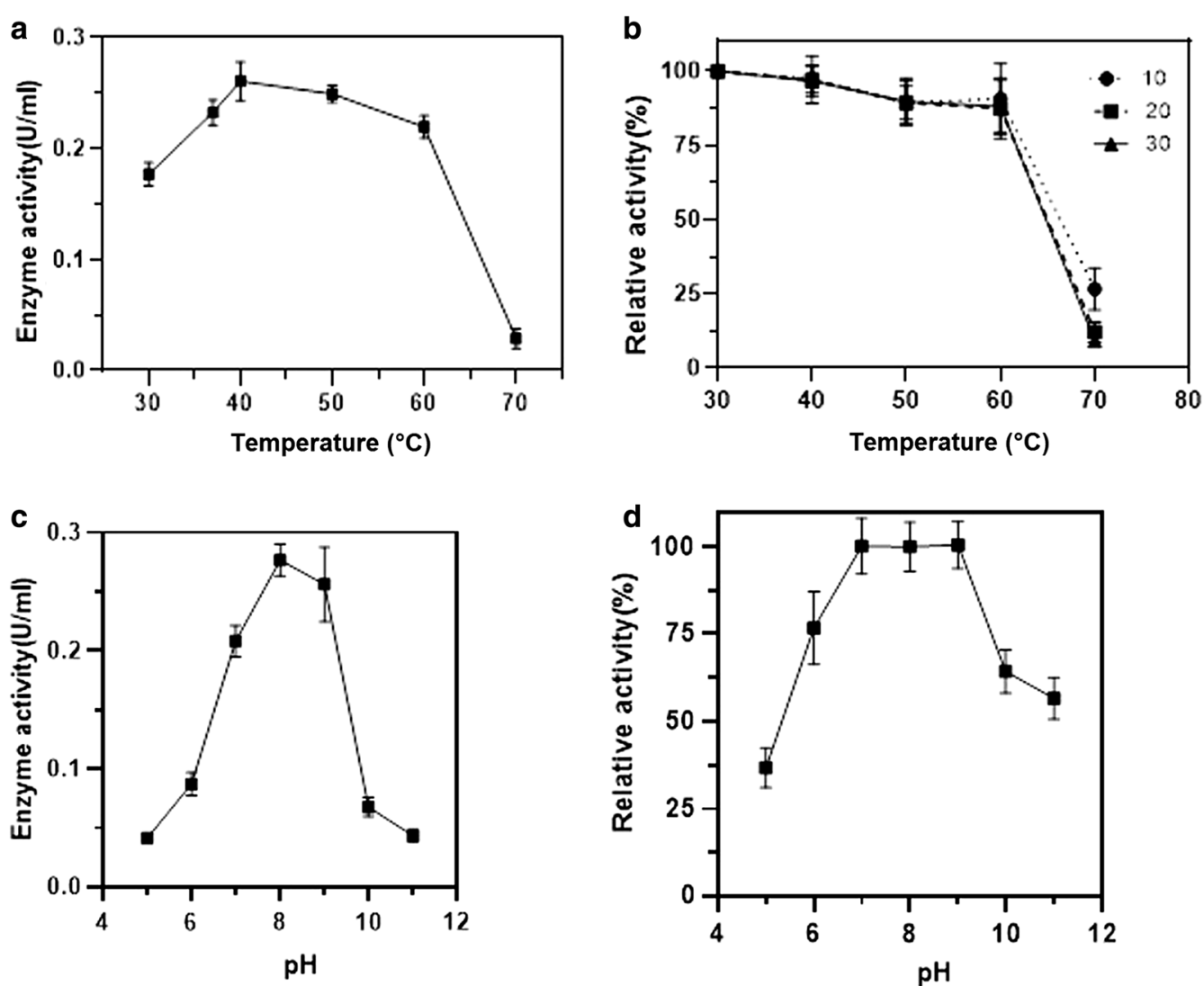

Fig. 5 a Temperature profile, $\mathbf{b}$ thermal stability, $\mathbf{c}$ pH profile, and $\mathbf{d}$ pH stability of HOD from Glutamibacter sp. N1A3101. Thermal stability was measured after incubation of $\mathrm{HOD}$ for 10,20 , and $30 \mathrm{~min}$ at temperatures $30-70^{\circ} \mathrm{C}$, and pH stability measured after 10 min incubation at $40{ }^{\circ} \mathrm{C}$. Error bars represent standard error $(n=3)$

by $16 \mathrm{~s}$ rRNA sequencing and confirmed as the Glutamicibacter sp. N1A3101 (GenBank: MN047236.1). The detected HOD showed good specificity toward histamine; no oxidase activity was identified for other tested BAs, including putrescine, Cadaverine, Spermine, Spermidine and amino acid L-histidine. The only slight activity was seen for Tyramine substrate (20\% of histamine), which was lower than other reported HODs (Shimizu et al. 1994; Sekiguchi et al. 2004).

According to the obtained results, this newly detected HOD is a thermostable alkaline enzyme with the maximum catalytic activity at $40{ }^{\circ} \mathrm{C}$ and $\mathrm{pH} 8$. Furthermore, the enzyme well tolerates the $\mathrm{pH}$ values of 7 to 9 . In terms of $\mathrm{pH}$ and temperature, this HOD enzyme showed 
Table 2 The effect of betahistine on HOD production in Glutamicibacter sp. N1 A3101

\begin{tabular}{|c|c|c|c|c|c|}
\hline $\begin{array}{l}\text { Experiment } \\
\#\end{array}$ & Histamine & Betahistine & $\mathrm{NH} 4 \mathrm{Cl}$ & Acetate & $\begin{array}{l}\text { HOD } \\
\text { activity (U/ } \\
\text { ml) }\end{array}$ \\
\hline 1 & - & + & - & - & 0 \\
\hline 2 & - & + & - & + & 0 \\
\hline 3 & - & + & + & + & 0.1 \\
\hline Control - & - & - & + & + & 0 \\
\hline Control + & + & - & - & + & 0.2 \\
\hline
\end{tabular}

similarity to the previously isolated HOD from A. crystallopoietes KAIT-B-007. However, it is notably considerable when compared to the other reported HODs. For instance, the HOD enzyme isolated from $A$. niger AKU3302 shows the maximum activity below $35{ }^{\circ} \mathrm{C}$ at $\mathrm{pH} 7$, with low thermostability. The $\mathrm{pH}$ and temperature characteristics, besides its specificity, make the isolated HOD a useful candidate for biosensor application.

HOD is an inducible enzyme, and the presence of histamine substrate is necessary for enzyme production. Histamine is a relatively expensive material, and not costeffective for large-scale production of HOD in the native microorganism. There are various strategies to reduce the production cost. For instance, optimizing the culture media, environmental conditions, cloning of the desired gene in another host, etc. (Chaikaew et al. 2015).

To address this issue, we investigated to find an alternative cheaper inducing agent. We hypothesized that compounds with histamine-like structures or those that are obtained from plants that produce histamine might induce gene expression through the effect on the gene regulatory sequences. Several candidate compounds such as spinach extract and nettle plant extract (data not represented), and a histamine chemical analogue (betahistine) were assayed, and betahistine was found that triggers the HOD production. Notably, betahistine was not consumed by Glutamicibacter sp. N1A3101 as nitrogen or carbon sources for growth, and functions explicitly as an inducer for HOD gene expression. The obtained HOD production with the betahistine needs to be optimized to be introduced as a suitable substrate for use in the industry.

To the best of our knowledge, no study has reported the betahistine as the inducer of HOD production. And further studies are necessary to describe the mechanism underlying the interaction of betahistine with the regulatory elements of HOD.

\section{Supplementary information}

Supplementary information accompanies this paper at https://doi. org/10.1186/s13568-020-01115-2.

Additional file 1: Table S1. Alighnment of HOD DNA sequences from different bacterial genuses. The sequences used for primer design were highlighted in yellow.

\section{Abbreviations}

BAs: Biogenic amines; HOD: Histamine oxidase; LB: Luria-Bertani; BSM: Basal salt medium; DAOS BDOAS:

$\mathrm{N}$-Ethyl-N-(2-hydroxy-3-sulfopropyl)-3,5-dimethoxyaniline.

Acknowledgements

The authors would like to thank the Sobhan Recombinant Protein Co. for its material and technical support.

\section{Authors' contributions}

$\mathrm{HS}$, GE and JF conceived and designed the research. HS, SORS, and GE conducted experiments. HS, SORS, and SA analyzed data. HS and SA wrote the manuscript. All authors read and approved the manuscript.

\section{Funding}

Not applicable.

\section{Availability of data and materials}

The datasets supporting the conclusions of this article are included within the article and its additional files. The GenBank accession number for 16S rRNA and newly isolated HOD gene reported in this manuscript are MN047236.1, and MT993978, respectively.

\section{Ethics approval and consent to participate}

This article does not contain any studies with human participants or animals performed by any of the authors.

\section{Consent for publication}

Not applicable.

\section{Competing interests}

The authors declare that they have no competing interests.

\section{Author details}

${ }_{1}^{1}$ Department of Microbiology \& Microbial Biotechnology, Faculty of Life Sciences and Biotechnology, Shahid Beheshti University, Tehran, Iran. ${ }^{2}$ Protein Research Center, Shahid Beheshti University, Tehran, Iran. ${ }^{3}$ Department of Biotechnology, Faculty of Biological Sciences, Alzahra University, Tehran, Iran.

Received: 1 September 2020 Accepted: 24 September 2020

Published online: 02 October 2020

\section{References}

Alvarez MA, Moreno-arribas MV (2014) The problem of biogenic amines in fermented foods and the use of potential biogenic microorganisms as a solution. Trends Food Sci Technol 39:146-155. https://doi.org/10.1016/j. tifs.2014.07.007

Biji KB, Ravishankar CN, Venkateswarlu R, Mohan CO (2016) Biogenic amines in seafood: a review. J Food Sci Technol. https://doi.org/10.1007/s1319 7-016-2224-x

Busse H-J, Schumann P (2019) Reclassification of Arthrobacter endophyticus as Glutamicibacter endophyticus comb. nov. Int I Syst Evol Microbiol 69:1057-1059

Chaikaew S, Powtongsook S, Boonpayung S, Benjakul S, Visessanguan W (2015) Enhanced production of histamine dehydrogenase by Natrinema gari BCC 24369 in a non-sterile condition. J Gen Appl Microbiol $61: 232-240$ 
Isobe K, Tani Y, Yamada H, Hiromi K (1980) Determination of polyamines with immobilized beef plasma amine oxidase. Agric Biol Chem 44:615-619

Ito T, Hiroi T, Amaya T, Kaneko S, Araki M (2009) Preliminary study of a microbeads based histamine detection for food analysis using thermostable recombinant histamine oxidase from Arthrobacter crystallopoietes KAITB-007. Talanta 77:1185-1190. https://doi.org/10.1016/j.talanta.2008.08.018

Köse S, Koral S, Tufan B, Buruk C, Aydın F (2011) Commercial test kits and the determination of histamine in traditional (ethnic) fish products-evaluation against an EU accepted HPLC method. 125:1490-1497. https://doi. org/10.1016/j.foodchem.2010.10.069

Lee J-I, Kim Y-W (2013) Characterization of amine oxidases from Arthrobacter aurescens and application for determination of biogenic amines. World J Microbiol Biotechnol 29:673-682

McGowan RE, Muir RM (1971) Purification and properties of amine oxidase from epicotyls of Pisum sativum. Plant Physiol 47:644-648

Pionetti J-M (1974) Analytical-band centrifugation of the active form of pig kidney diamine oxidase. Biochem Biophys Res Commun 58:495-498

Rosini E, Tonin F, Vasylieva N, Marinesco S, Pollegioni L (2014) Evolution of histamine oxidase activity for biotechnological applications. Appl Microbiol Biotechnol 98:739-748

Sekiguchi Y, Nishikawa A, Makita H (2001) Flow-through chemiluminescence sensor using immobilized histamine oxidase from Arthrobacter crystallopoietes KAIT-B-007 and peroxidase for selective determination of histamine. Anal Sci 17:1161-1164
Sekiguchi Y, Makita H, Yamamura A, Matsumoto K (2004) A thermostable histamine oxidase from Arthrobacter crystallopoietes KAIT-B-007. J Biosci Bioeng 97:104-110

Shimizu E, Odawara T, Tanizawa K, Yorifuji T (1994) Histamine oxidase, a Cu2 +-quinoprotein enzyme of Arthrobacter globiformis. Biosci Biotechnol Biochem 58:2118-2120

Suzuki H (1971) Stoichiometry of the reaction by amine oxidase from Aspergillus niger. J Biochem 69:1065-1074

Velut G, Delon F, Mérigaud JP, Tong C, Duflos G, Boissan F, Watier-Grillot S, Boni M, Derkenne C, Dia A, Texier G, Vest P, Meynard JB, Fournier PE, Chesnay A, Pommier de Santi V (2019) Histamine food poisoning: a sudden, large outbreak linked to fresh yellowfin tuna from Reunion Island, France, April 2017. Euro Surveill 24:1800405. https://doi.org/10.2807/1560-7917. ES.2019.24.22.1800405

Yang T, Kim Y-J, Roy JK, Kim Y-W (2019) Combined cross-linked enzyme aggregates of monoamine oxidase and putrescine oxidase as a bifunctional biocatalyst for determination of biogenic amines in foods. Catalysts 9:579

\section{Publisher's Note}

Springer Nature remains neutral with regard to jurisdictional claims in published maps and institutional affiliations.

\section{Submit your manuscript to a SpringerOpen ${ }^{\odot}$ journal and benefit from:}

- Convenient online submission

- Rigorous peer review

- Open access: articles freely available online

- High visibility within the field

- Retaining the copyright to your article

Submit your next manuscript at $>$ springeropen.com 